\title{
ĐẶC ĐIỂM DI CĂN HẠCH TRÊN CT SCAN ĐỐI CHIẾU VỚI TỔN THƯƠNG TRONG MỔ VÀ MÔ BỆNH HỌC CỦA UNG THƯ PHỔI KHÔNG TẾ BÀO NHỎ ĐƯợC ĐIỀU TRỊ BẰNG PHẪU THUẬT TẠI BỆNH VIỆN QUÂN Y 103
}

\author{
Nguyễn Truờng Giang*, Nguyễn Ngọc Trung*, Nguyễn Văn Nam*, Nguyễn Thế Kiên *
}

\section{TÓM TẮT}

Trong thời gian 26 tháng từ tháng 01 năm 2014 đến tháng 03 năm 2016, tại khoa phẫu thuật Lồng ngực - Tim mạch, Bệnh viện Quân y 103 đã tiến hành phẫu thuật cắt thùy, nạo vét hạch cho 29 trường hợp ung thư phổi nguyên phát, tuổi trung bình 58,62 với 93,10\% là nam giới. Trong đó có 28 bệnh nhân cắt 1 thùy phổi $(96,55 \%), 1$ bệnh nhân cắt 2 thùy phổi $(3,45 \%)$, không có bệnh nhân nào cắt toàn bộ 1 phổi. Phân loại mô bệnh học: ung thư biểu mô tuyến $62,07 \%$, ung thư biểu mô tế bào vảy $21,14 \%$, ung thư biểu mô kém biệt hóa 10,34\%, ung thư biểu mô tế bào sáng 3,45\%. Chẩn đoán trước mổ chỉ 3,45\% trường hợp xác định rõ hạch trên CTscan. 29 tường hợp đều được ghi nhận có hạch trong mổ, trong đó hạch số 10 chiếm tỉ lệ cao nhất ( 21 tường hợp, 72,4\%), tiếp đến hạch số 4 và hạch số 9 với lần lượt là $24,1 \%$ và $20,4 \%$. Mô bệnh học hạch sau mổ có 8 trường hợp $(27,59 \%)$ có di căn hạch, trong số này phù hợp với PET-CT là $75 \%$, di căn hạch số 4 chiếm tỷ lệ cao nhất với $50 \%$.

Study on characteristics of lymph node metastasis using CT Scan diagnosis in comparison with surgical and histopathological findings in patients with non-small cell lung cancer underwent lobectomy at 103 Military Hospital

\section{SUMMARY}

Within 26 months (01/2014 - 03/2016), 29 patients who were diagnosed with the lung cancer disease, and underwent lobectomy surgery at cardiothoracic department of 103 Military hospital. The mean age was 58,$62 ; 93.10 \%$ was male; lobectomy surgery was performed on 28 patients $(95,55 \%)$, bilobectomy surgery was implemented on 1 patient $(3,45 \%)$. Histopathological analysis: adenocarcinoma $(62,07 \%)$, squamous cell carcinoma $(24,14 \%)$, undifferentiated pulmonary carcinoma $(10,34 \%)$, clear cell carcinoma $(3,45 \%)$. Pre-operative CT Scan diagnosis identified the lymph node metastasis with the low percentage of $3,45 \%$, while $100 \%$ being determined during the operation. In which lymph node groups 10, 4, 9 make up $72,42 \%, 17,24 \%, 10,34 \%$ respectively. The histopathological analysis identified lymph node metastasis in 8 cases $(27,59 \%)$. These cases were correlated with PET-CT 75\%, lymph node metastasis in group 4 make up the highest percentage of $50 \%$.

\section{I. ĐặT VẤN ĐỂ}

Ung thư phổi nguyên phát chiếm tỷ lệ cao và là nguyên nhân gây tử vong hàng đầu trong tất cả các loại bệnh ung thư. Trên thế giới trong số khoảng 12,7 triệu trường hợp ung thư mới mắc được chẩn đoán hàng năm, ung thư phổi nguyên phát chiếm 1,61 triệu trường hợp ( 12,7\%), với 1,38 triệu trường hợp tử vong. Tại Việt Nam, ung thư phổi nguyên phát có xuất độ cao, đặc biêt ở nam giới, với tỷ lệ 24,6 bệnh nhân / 100.000 dân tại khu vực Thành phố Hồ Chí Minh và 38,8 bệnh nhân / 100.000 dân tại khu vực Hà Nội. Từ năm 20052006, trong 93.719 trường hợp tử vong do ung thư trong đó có 22.209 do ung thư phổi.[1], [3], [6].

* Khoa Phẫu thuật Lồng ngực - Tim mạch, Bệnh viện Quân y 103 Người chịu trách nhiệm khoa hoc: PGS.TS. Nguyễn Trưòng Giang Ngày nhận bài: 15/10/2016 - Ngày Cho Phép Đăng: 05/11/2016 Phản Biện Khoa học: PGS.TS. Đặng Ngọc Hùng GS.TS. Bùi Đúc Phú 
Đa số các trường hợp ung thư phổi được phát hiện ở giai đoạn muộn không còn khả năng điều trị triệt để. Theo hầu hết các tài liệu thống kê trong và ngoài nước thì chỉ có khoảng 15-20\% bệnh nhân ung thư phổi được phát hiện ở giai đoạn còn có khả năng phẫu thuật điều trị triệt để. Phát hiện sớm, chẩn đoán chính xác giai đoạn và lựa chọn phương pháp điều trị tối ưu góp phần nhìn nhận rõ hơn bức tranh toàn cảnh về ung thư phổi.

Các nghiên cứu về ung thư phổi đã được thực hiện nhiều ở các trung tâm lớn trong và ngoài nước, tuy nhiên các kết quả nghiên cứu đánh giá về tình trạng di căn hạch rốn phổi và trung thất đối chiếu với chụp $\mathrm{CT}$ mổ trước và kết quả mô bệnh học hạch sau mổ còn rất khác nhau. Vì vậy, chúng tôi tiến hành nghiên cứu này nhằm mục đích: đánh giá tình trạng di căn hạch so sánh giữa kết quả chụp $\mathrm{CT}$ Scan và tổn thương trong mổ trong ung thư phổi tế bào không nhỏ.

\section{II. ĐỐI TƯợNG, PHƯƠNG PHÁP NGHIÊN CÚU}

\section{1. Đối tượng nghiên cứu}

Bệnh nhân ung thư phổi được điều trị bằng phẫu thuật tại Khoa phẫu thuật Tim mạch- Lồng ngực, Bệnh viện Quân Y 103, thời gian từ tháng 1 năm 2014 đến tháng 3 năm 2016.

\subsection{Phương pháp nghiên cứu}

- Thiết kế nghiên cứu: nghiên cứu tiến cứu mô tả cắt ngang.

- Bệnh nhân ung thư phổi được đánh giá các đặc điểm:

+ Tuổi, giới.

+ Các triệu chứng lâm sàng.

+ Các xét nghiệm: CT scan, PET-CT đánh giá: vị trí khối u, kích thước khối u $(\mathrm{cm})$, hạch rốn phổi, hạch trung thất

- Tất cả các bệnh nhân được đánh giá giai đoạn, xét chỉ định phẫu thuật, chuẩn bị mổ theo quy trình thống nhất.
- Số lượng hạch cụ thể trong mổ.

- Mô bệnh học khối u và hạch sau mổ.

- Phương pháp xử lý số liệu: số liệu được xử lý trên phần mềm SPSS 16.0.

\section{KẾT QUẢ NGHIÊN CÚU}

\section{Bảng 3.1: Tuổi và giới}

\begin{tabular}{|l|c|c|c|}
\hline Giới tính & $\mathbf{n =}$ & $\begin{array}{c}\text { Khoảng } \\
\text { dao động }\end{array}$ & $\begin{array}{c}\text { Tuổi trung } \\
\text { bình }\end{array}$ \\
\hline Nam & 27 & $36-80$ & 58,59 \\
\hline Nữ & 2 & $55-63$ & 59 \\
\hline Tổng & 29 & $36-80$ & 58,62 \\
\hline
\end{tabular}

Tuổi trung bình cho cả nam và nữ là 58,62

Bệnh nhân trẻ nhất 36 tuổi, bệnh nhân lớn tuổi nhất 80 tuổi, cả 2 đều là nam giới. Có 2 trường hợp nữ 55 và 63 tuổi.

Tỷ lệ nam/ nữ: 13,5/1.

Bảng 3.2: Triệu chứng lâm sàng

\begin{tabular}{|l|c|c|}
\hline Triệu chứng lâm sàng & $\begin{array}{c}\text { Số bệnh } \\
\text { nhân }\end{array}$ & Tỷ lệ \% \\
\hline Ho khan & 23 & 79,31 \\
\hline Ho máu & 4 & 13,79 \\
\hline Đau tức ngực & 21 & 72,41 \\
\hline Gầy sút cân & 8 & 27,59 \\
\hline Tình cờ đi khám sức khỏe & 4 & 13,79 \\
\hline
\end{tabular}

Triệu chứng thường gặp nhất là ho khan, đau tức ngực, sau đó đến gầy sút cân.

Bảng 3.3: CT scan lồng ngực có thuốc cản quang

\begin{tabular}{|l|l|c|c|}
\hline STT & Đặc điểm CT scan & Số bệnh nhân & Tỷ lệ \% \\
\hline 1 & Kích thước u & & \\
& $\leq 2 \mathrm{~cm}$ & 4 & 13,79 \\
& 2 đến $\leq 3 \mathrm{~cm}$ & 10 & 34,48 \\
& 3 đến $\leq 5 \mathrm{~cm}$ & 10 & 34,48 \\
& 5 đến $\leq 7 \mathrm{~cm}$ & 3 & 10,34 \\
& $>7 \mathrm{~cm}$ & 2 & 6,91 \\
\hline
\end{tabular}




\begin{tabular}{|l|l|c|c|}
\hline 2 & Vị trí & & \\
& Thùy trên (P) & 11 & 37,93 \\
& Thùy giữa (P) & 0 & 0 \\
& Thùy dưới (P) & 7 & 24,14 \\
& Thùy trên (T) & 8 & 27,59 \\
& Thùy dưới (T) & 3 & 10,34 \\
& Thùy trên + giữa $(\mathrm{P})$ & 0 & 0 \\
& Thùy dưới+giữa (P) & 0 & 0 \\
& Thùy trên + dưới $(\mathrm{T})$ & 0 & 0 \\
\hline 3 & Hạch rốn phổi & 1 & 3,45 \\
\hline 4 & Hạch trung thất & 1 & 3,45 \\
\hline 5 & Xâm lấn thành ngực & 1 & 3,45 \\
\hline
\end{tabular}

Trên chụp CT scan lồng ngực có tiêm thuốc cản quang, kích thước khối u chủ yếu ở T1b và T2a, chiếm đến $68,96 \%$, phần lớn các khối u ngấm thuốc cản quang mạnh sau tiêm, phần nào đã giúp xác định được bản chất ác tính của khối u. Chỉ có 1 trường hợp xác định hạch trung thất và hạch rốn phổi rõ trên phim chụp CT scan lồng ngực, còn lại việc xác định có hạch trung thất và hạch rốn phổi khó khăn.

\section{Bảng 3.4: Kết quả chụp PET-CT}

\begin{tabular}{|l|c|c|c|c|c|c|}
\hline & $\begin{array}{c}\mathbf{U} \\
\text { thùy } \\
\text { trên } \\
(\mathbf{P})\end{array}$ & $\begin{array}{c}\mathbf{U} \\
\text { thùy } \\
\text { dưới } \\
\text { (P) }\end{array}$ & $\begin{array}{c}\text { U } \\
\text { thuỳ } \\
\text { trên } \\
\text { (T) }\end{array}$ & $\begin{array}{c}\text { U } \\
\text { thùy } \\
\text { dưới } \\
\text { (T) }\end{array}$ & $\begin{array}{c}\text { Di } \\
\text { căn } \\
\text { hạch } \\
\text { nhóm } \\
\text { N1 }\end{array}$ & $\begin{array}{c}\text { Di } \\
\text { căn } \\
\text { hạch } \\
\text { nhóm } \\
\text { N2 }\end{array}$ \\
\hline $\begin{array}{l}\text { Số } \\
\text { BN }\end{array}$ & 1 & 0 & 2 & 1 & 2 & 2 \\
\hline$\%$ & 25 & 0 & 50 & 25 & 100 & 50 \\
\hline $\begin{array}{l}\text { Đối } \\
\text { chiếu } \\
\text { MBH } \\
\text { hạch }\end{array}$ & & & & & 2 & 1 \\
\hline
\end{tabular}

Trong 4 bệnh nhân được chụp PET-CT thì có 2 bệnh nhân xác định có di căn nhóm hạch N1, 2 trường hợp xác định có di căn nhóm hạch N2, đồi chiếu với mô bệnh học hạch sau mổ thì nhóm $\mathrm{N} 1$ đúng $100 \%$, còn nhóm N2 có 1 bệnh nhân ghi nhận là hạch viêm (chiếm 50\%).

\section{Bảng 3.5: Các nhóm hạch trong mổ}

\begin{tabular}{|l|c|c|c|c|c|c|c|c|c|c|c|c|c|c|}
\hline Hạch & 1 & 2 & 3 & 4 & 5 & 6 & 7 & 8 & 9 & 10 & 11 & 12 & 13 & 14 \\
\hline Số BN & 0 & 1 & 0 & 7 & 3 & 1 & 4 & 1 & 6 & 21 & 2 & 1 & 1 & 0 \\
\hline$\%$ & 0 & 3,4 & 0 & 24,1 & 10,3 & 3,4 & 13,7 & 3,4 & 20,4 & 72,4 & 6,8 & 3,4 & 3,4 & 0 \\
\hline
\end{tabular}

Cả 29 bệnh nhân đều được nạo vét hạch trong mổ, trong đó hạch số 10 chiếm tỉ lệ cao nhất với $72,4 \%$, tiếp đến hạch số 4 và hạch số 9 với lần lượt là $24,1 \%$ và $20,4 \%$

Bảng 3.6: Phương pháp phẫu thuật

\begin{tabular}{|l|c|c|}
\hline Phương pháp phẫu thuật & Số bệnh nhân & Tỷ lệ \% \\
\hline Cắt 1 thùy phổi & 28 & 96,55 \\
\hline Cắt 2 thùy phồi & 1 & 3,45 \\
\hline Cắt toàn bộ 1 bên phồi & 0 & 0 \\
\hline
\end{tabular}

Hầu hết các trường hợp được phẫu thuật cắt 1 thùy phổi và nạo vét hạch hệ thống với 96,55\%, chỉ có 1 trường hợp chiếm $3,45 \%$ cắt 2 thùy phổi vì khối u ở thùy trên xêm lấn sang thùy giữa phổi phải.

Bảng 3.7: Kết quả mô bệnh học

\begin{tabular}{|l|c|c|}
\hline Kết quả mô bệnh học & Số BN & \% \\
\hline Ung thư biểu mô tuyến (BMT) & 18 & 62,07 \\
\hline Ung thư biểu mô tế bào vảy (TBV) & 7 & 24,14 \\
\hline Ung thư biểu mô kém biệt hóa (KBH) & 3 & 10,34 \\
\hline Ung thư biểu mô tế bào sáng (TBS) & 1 & 3,45 \\
\hline
\end{tabular}


Ung thư biểu mô tuyến $(62,07 \%)$ chiếm tỷ lệ vượt trội so với các typ ung thư khác.

Bảng 3.8: Tình trạng di căn hạch

\begin{tabular}{|l|c|c|c|c|c|c|}
\hline & Số BN & Hạch số 2 & Hạch số 4 & Hạch số 10 & Hạch số 9 & $\%$ \\
\hline Hạch di căn & 8 & 1 & 4 & 2 & 1 & 27,59 \\
\hline Hạch viêm & 21 & & & & & 72,41 \\
\hline$\%$ & & 12,5 & 50 & 25 & 12,5 & 100 \\
\hline
\end{tabular}

Trong số 8 bệnh nhân xác định có di căn hạch chiếm $27,59 \%$, thì di căn hạch số 4 chiếm tỷ lệ $50 \%$.

\section{BÀN LUẬAN}

4.1. Đặc điểm của ung thư phổi được điều trị bằng phẫu thuật

Ung thư phổi là bệnh lý khá thường gặp, trong thời gian 26 tháng qua tại Khoa phẫu thuật Lồng ngực và Tim mạch, bệnh viện Quân Y 103 chúng tôi tiến hành phẫu thuật cắt thùy cho 29 bệnh nhân. Triệu chứng lâm sàng chủ yếu là ho khan ( 23 trường hợp, 79,31\%) và đau tức ngực (21 trường hợp, 72,41\%). Hai triệu chứng này cao hơn các tác giả khác là $32,7 \%$ và $20 \%$ [5].

Số bệnh nhân phát hiện tình cờ đi khám sức khỏe chiếm tỷ lệ cao ( 4 trường hợp, 13,79\%). Điều này tương đương với các nghiên cứu của các tác giả khác [2], [6].Những khối u phát hiện tình cờ thường nhỏ, ở giai đoạn $\mathrm{I}$. Kết quả này hoàn toàn phù hợp giai đoạn bệnh sau mổ với 18 bệnh nhân giai đoạn IA và IB chiếm $62,07 \%$.

Tỷ lệ nam giới / nữ giới của chúng tôi là 13,5/1, cao hơn các tác giả khác [1], [4].Điều này có thể được giải thích một phần do chúng tôi là bệnh viện tuyến quân đội nên cũng có sự chênh lệch đáng kể giữa nam giới và nữ giới.

4.2. Vị trí tổn thương và hạch trên $\mathrm{CT}$ scan lồng ngực

Tổn thương nằm ở bên phổi phải nhiều hơn 18 trường hợp chiếm $62,07 \%$. Trong đó thùy trên chiếm tỷ lệ cao với 11/18 trường hợp, 61,11\%. Nhận định này cũng giống một số tác giả khác [7]. Tuy nhiên cho đến nay vẫn chưa lý giải được tại sao ung thư phổi ở phổi phải chiếm tỷ lệ cao hơn phổi trái. Do cấu tạo về giải phẫu học, nên với những khối u bên phổi phải việc phẫu thuật cắt thùy điều trị ung thư dễ hơn phổi trái. Trong phẫu thuật cắt thùy, khó nhất là cắt thùy trên phổi trái, nếu không cẩn thận sẽ làm tổn thương nhánh động mạch của thùy dưới phổi trái, gây hoại tử hoặc mất chức năng thùy dưới.

Chỉ có $3,45 \%$ trường hợp xác định rõ ràng có hạch trung thất và hạch rốn phổi trên CTscan lồng ngực có tiêm thuốc cản quang. Hầu hết các trường hợp còn lại đều khó khăn trong việc xác định hạch trên CTscan. Kết quả nghiên cứu của chúng tôi thấp hơn so với nghiên cứu của Chung Giang Đông và Đỗ Kim Quế 85,4\% hạch rốn phổi và $47,2 \%$ hạch trung thất [1]. Có thể do nhóm bệnh nhân của chúng tôi có đến $62,07 \%$ giai đoạn $\mathrm{IA}$ và $\mathrm{IB}$, còn của tác giả $70,3 \%$ giai đoạn IIIA và IIIB nên việc xác định hạch trên CT scan là khác nhau. Theo Lê Sỹ Sâm và $C S$ thì kích thước khối u càng lớn thì tỷ lệ di căn hạch càng cao[4].

\subsection{Về di căn hạch trên PET-CT đối chiếu với mô bệnh hạch sau mổ.}

Cả 4 trường hợp chụp PET-CT được xác định có di căn hạch, trong đó 2 trường hợp di căn hạch nhóm N1, 2 trường hợp di căn hạch nhóm N2. Đối chiếu với mô bệnh hạch sau mổ thì nhóm $\mathrm{N} 1$ phù hợp $100 \%$, còn nhóm N2 chỉ phù hợp $50 \%$. Rõ ràng việc xác định di căn hạch trên PET$\mathrm{CT}$ có ưu thế hơn hẳn trên $\mathrm{CT}$ scan. Tuy nhiên do giá thành cao nên chỉ có 4 bệnh nhân được chụp PET-CT nên chưa thể xác định được quy luật di căn nhóm hạch cụ thể. 


\subsection{Nạo vét hạch trong mổ đối chiếu với kết quả mô bệnh hạch}

Trong điều trị ung thư nói chung, ung thư phổi nói riêng, nạo vét hạch là công việc quan trọng thứ 2 sau phẫu thuật cắt rộng rãi khối u. Nó có giá trị trong việc loại bỏ tối đa tế bào ung thư ra khỏi cơ thể bệnh nhân, xác định chính xác giai đoạn, giúp cho quá trình điều trị hỗ trợ hậu phẫu và tiên lượng bệnh.Tất cả 29 bệnh nhân của chúng tôi đều được nạo vét hạch, trong đó hạch số 10 chiếm tỷ lệ cao nhất 21 trường hợp, 72,4\%, tiếp đến hạch số 4 và hạch số 9 với lần lượt là $24,1 \%$ và $20,4 \%$. Đối chiếu với mô bệnh hạch sau mổ chỉ có 8 trường hợp, $27,59 \%$ có di căn hạch, trong đó di căn hạch số 4 chiếm 4 trường hợp, $50 \%$, hạch số 10 là 2 trường hợp, $25 \%$, hạch số 2 và hạch số 9 có 1 trường hợp, 12,5\%.

Trong số 8 trường hợp xác định có di căn hạch, thì có 2 trường hợp thùy trên phải di căn hạch số 4,2 trường hợp thùy trên trái di căn hạch số 10 , thùy dưới phải:1 trường hợp di căn hạch số 2, 1 trường hợp di căn hạch số 4,1 trường hợp di căn hạch số 10 và 1 trường hợp di căn hạch số 9 . Nhận định này một phần phù hợp với đặc điểm di căn hạch bạch huyết của ung thư phổi [1], [7], [8], tuy nhiên do số liệu còn ít, cần được nghiên cứu thêm.

\section{5. Đặc điểm mô bệnh học ung thư phổi} không tế bào nhỏ được điều trị bằng phẫu thuật

Ung thư biểu mô tuyến chiếm tỷ lệ cao vượt trội ( 18 trường hợp, 62,07\%), tiếp đến ung thư biểu mô tế bào vảy ( 7 trường hợp, 24,14\%). Kết quả này hoàn toàn phù hợp với các nghiên cứu của các tác giả trong và ngoài nước [2],[4],[8].

\section{KẾT LUẬN}

Trong thời gian 26 tháng từ tháng 01 năm 2014 đến tháng 03 năm 2016, chúng tôi đã tiến hành phẫu thuật cắt thùy, nạo vét hạch cho 29 trường hợp ung thư phổi nguyên phát, kết quả thu được như sau:

- Tuổi trung bình 58,62 với 93,10\% là nam giới. Trong đó có 28 bệnh nhân cắt 1 thùy phôi $(96,55 \%), 1$ bệnh nhân cắt 2 thùy phổi $(3,45 \%)$, không có bệnh nhân nào cắt toàn bộ 1 phổi.

- Phân loại mô bệnh học: ung thư biểu mô tuyến $62,07 \%$, ung thư biểu mô tế bào vảy 21,14\%, ung thư biểu mô kém biệt hóa 10,34\%, ung thư biểu mô tế bào sáng 3,45\%.

- Chẩn đoán trước mổ chỉ 3,45\% trường hợp xác định rõ hạch trên CTscan. 29 tường hợp đều được ghi nhận có hạch trong mổ, trong đó hạch số 10 chiếm tỉ lệ cao nhất ( 21 tường hợp, $72,4 \%$ ), tiếp đến hạch số 4 và hạch số 9 với lần lượt là $24,1 \%$ và $20,4 \%$. Mô bệnh học hạch sau mổ có 8 trường hợp $(27,59 \%)$ có di căn hạch, trong số này phù hợp với PET-CT là $75 \%$, di căn hạch số 4 chiếm tỷ lệ cao nhất với $50 \%$.

\section{TÀI LIỆ THAM KHẢO}

1. Chung Giang Đông, Đỗ Kim Quế (2007). Giá trị của CT scan trong chẩn đoán di căn hạch của ung thư phổi nguyên phát, Tạp chí y học Tp Hồ Chí Minh. Tập 11. Phụ bản của Số 1 .

2. Nguyễn Hoài Nam (1996). Một số nhận xét về hình thái giải phẫu bệnh lý qua 54 trường hợp ung thư phổi được mổ tại bệnh viện Chợ rẫy. Hình thái học, tập 6, số 2, tr:25-26.

3. Nguyễn Hoài Nam (2003). Nghiên cứu hình thái giải phẫu bệnh và lâm sàng của ung thư phổi được điều trị bằng phẫu thuật. Tap chí y hoc Tp Hồ Chí Minh. Tập 7. Phụ bản của Số 1 .

4. Lê Sỹ Sâm, Đỗ Kim Quế (2007). Kích thước khối u có lien quan với nguy cơ di căn hạch và tỷ lệ sống còn trong ung thư phổi không tế bào nhỏ.,Tạp chí y hoc Tp Hồ Chí Minh. Tập 11. Phu bản của Số 1 . 
5. Broderick SR, Patterson GA.(2013). Performance of integrated positron emission tomography/computed tomography for mediastinal nodal staging in non-small cell lung carcinoma. Thorac Surg Clin. May;23(2):193-8. doi: 10.1016/j.thorsurg.2013.01.014. Epub 2013 Feb 19. Review.

6. Choi CM, Kim MY, Hwang HJ, Lee JB, Kim WS.(2015). Advanced adenocarcinoma of the lung: comparison of CT characteristics of patients with anaplastic lymphoma kinase gene rearrangement and those with epidermal growth factor receptor mutation. Radiology. Apr;275(1):272-9. doi: 10.1148/radiol.14140848. Epub 2015 Jan 7.
7. Kudo S, Imai $\mathrm{K}$, Ishiyama $\mathrm{K}$, Hashimoto M, Saito H, Motoyama S, Sato Y, Takashima S, Murata K, Minamiya Y.(2014). New CT criteria for nodal staging in non-small cell lung cancer. Clin Imaging. JulAug;38(4):448-53. doi: 10.1016/j.clinimag.2014.02.008. Epub 2014 Feb 15.

8. Pak K, Park S, Cheon GJ, Kang KW, Kim IJ, Lee DS, Kim EE, Chung JK. (2015). Update on nodal staging in non-small cell lung cancer with integrated positron emission tomography/computed tomography: a metaanalysis. Ann Nucl Med. Jun;29(5):409-19. doi: 10.1007/s12149-015-0958-6. Epub 2015 Feb 6. 